This rationality cannot be understood by the yardstick of the military discipline, of the patriarchal authority, of the instrumental rationality proper to the engineers, or of the capitalist rationality proper to the economists, for the reason that it is formulated largely in reaction to these four rationalities. Precisely, the second managerial rationality constitutes a new understanding of the way of governing individuals, which we call a "governmentality," in a way slightly different from Foucault. This managerial governmentality cannot be fit into a unique organizational frame, but circulates between different institutions, the most prominent being the family, the business corporation, and the State. The study of this new governmentality is the occasion to question the main views of government prevailing on both sides of the Atlantic for a century and a half, and thus to contribute to clarifying the contemporary ways of thinking about power.

The general schemes of thought used in the twentieth century to apprehend power, whether they are inspired by Marx, Weber, the Frankfurt School, or Foucault, focus on certain types of domination, which are mainly State-owned, military, disciplinary, legal, physical, capitalist, and technical. But, on the whole, these intellectual frameworks leave aside the logic of power proper to management. Nowadays, while this managerial governmentality is applied to the bulk of human activities, management is still thought of mainly as a loose and neutral set of technical arrangements, best practices, and universal recipes, the adoption of which is a matter of common sense and a guarantee of efficiency. Most of the histories and theories of management, far from questioning the origins, the evolutions, and the mechanisms of this governmentality, hold a discourse largely hagiographic and instrumental. For instance, rather than explaining how and why the value of efficiency came to gain precedence over yesterday's socially praised principles of brute force, justice, honesty, loyalty, equality, seniority, and freedom, a majority of theoreticians and historians of management contribute to extend, naturalize, and justify its symbolic prominence. Calling for a change, this research makes a case for theory of managerial governmentality and for a new history of management thought.

\title{
THE ECONOMIC APPROACH TO HUMAN BEHAVIOR: A HISTORICAL REVIEW AND AN ATTEMPT TO COMBINE IT WITH OTHER APPROACHES
}

\author{
DOTAN LESHEM
}

Supervisors: Ariella Azoulay and Yuval Yonay

University: Bar Ilan University

Date of Convocation: June 2010

Language: Hebrew 
My dissertation presents a genealogy of the definition of economy and its intricate relations with philosophical life, politics, and the boundaries set by law. Embarking on this task, I examine three moments in the history of the economy in the pre-modern era: the Classical moment, addressed in chapter 1; the Imperial moment, addressed in chapter 2; and the Christian moment, covered in the subsequent five chapters. In the concluding chapter, I offer a tentative account of how contemporary economy is configured in relation to political community, philosophical life, and the law, as well as other ways in which we may rethink its configuration in the present. The study was carried out by analyzing pre-modern texts referencing the term 'economy,' while examining the meaning given to this term in each of the different moments.

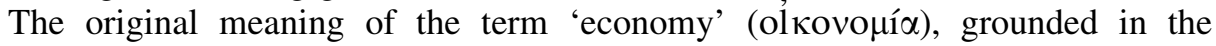
Classical moment, refers to the activity of the organization and management ( $v \varepsilon \dot{\varepsilon} \mu \varepsilon \iota v$ ) of a household (oĺко $)$. In the Imperial moment, the economy surpassed the confines of the household, as people began to be regarded as economizing in all spheres of life, and various arts and sciences received their own economies. The meaning of the word 'economy' in the Christian moment stemmed from the interpretation given by the Church Fathers to the term's appearance in the Pauline epistles: it referred to the realization of God's plan of salvation, from the beginning of the world to the fullness of ages. At the heart of this plan is the incarnation of the Son of God in the son of man in what came to be known as "the economy of the incarnation." Even though the word 'economy' appears in ecclesiastical writings thousands of times and with various meanings, in the great majority of cases the term appears in the context of the "economy

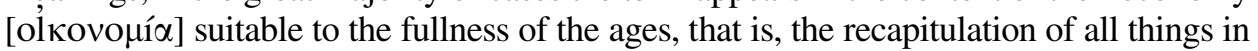
Christ, things in the heavens and things on the earth" (Ephesians 1:10).

The analysis of the various appearances of the term 'economy' in the premodern era enables me to demonstrate how, in each of the moments: i) a human condition manifested in the economy; ii) economy's inner organization is modeled and constituted; iii) the nature of the thing economized is rendered intelligible; and iv) economy's relations with politics, philosophy, and the boundaries set by law are constituted. The definitions of economy in the Classical and Christian moments appear rather similar. In each of these moments, faced with the human condition of excess, the individual has to acquire a theoretical and practical disposition of prudence for the purpose of generating surplus. Contrary to these two moments, common to the many different applications of 'economy' in the Imperial moment is the absence of either excess or surplus (and usually of both) from the various definitions. In this moment, 'economy' is understood as the acquisition of a theoretical and practical disposition of prudence. In moving from the Classical moment to the Christian moment, a change occurs in the human condition manifested in the economy. While, in the Classical moment, the economy is seen as corresponding to the mundane condition of necessity, in the Christian moment, it is seen as corresponding to the divine condition of freedom. Common to the understanding of the economy in both these moments is the notion that, ultimately, human action necessarily generates surplus. The greatest transformation occurs in the nature of the thing economized. While, in the Classical moment, the economized object is the needs of the life process itself, common to human and all other living beings, in the Christian moment, the divine within man 
is economized; i.e., that which man and God hold in common. In-between these two moments stands the Imperial moment, wherein all spheres of life and various sciences and theories received their own economies.

The relations between the economy, politics, philosophical life, and the boundaries set by law underwent far-reaching changes in the pre-modern era. After philosophical life and the political community were distinguished from economy, thereby establishing it as a distinct sphere, in the Classical moment, the law was used to exclude it from the political domain. Economy was now located outside the boundaries of law, and regarded as a sort of slave laboring in the service of the political community and philosophical life. In the Imperial moment, the term 'economy' was used to define governance in all spheres of existence, the polis not excluded. Economy's relations with philosophical life also underwent changes in the Imperial moment, with the products of philosophical life economized before they could be expressed in speech. In the Christian moment, we witness the advent of a new realm of life, the society of believers, in which the economy of salvation takes place. The growth of the Christian economy was seen as diachronically limited, so that in the fullness of ages, when all things are recapitulated in Christ, it will encompass both the private and the political realms. In this moment, the law once again served as economy's boundary, this time to include rather than exclude it. Starting in the fourth century, the relations between the economy and philosophical life also changed, as philosophical life was contained within the economy. This inclusion accompanied a tripartite partition of space: i) theological "space," found outside space and time and beyond the reach of human consciousness; ii) economic space, where the divine reveals itself in the society of believers; and iii) secular life, encompassing both the political and the private. This new way of dividing space occurred in tandem with a dramatic shift in the relationship between economy and politics as compared with the Classical moment. Politics was now seen as a sphere of necessity that slaves in the service of the economy, which is where people exercise their freedom.

Reconstructing the Christian moment allows me to argue that in the fourth century C.E., we witness the emergence of several new phenomena typically associated with the modern age: the emergence of a (Christian) society whose main concern is the growth of the (divine) economy; the emergence of a distinction between economy and theology; the subjugation of politics to the economy; the migration of freedom from the realm of politics to that of the economy; the designation of politics as the sphere entrusted with a monopoly over the means of legal violence; the economization of philosophical life; and the understanding of the law as acting in the service of the economy and as demarcating the outer boundaries that economy may sometimes overstep. 